\title{
Further Notes on Intrafascicular Cambium in Monocotyledons.
}

$\mathrm{BI}$

\section{AGNES ARBER.}

With four Figures in the Text.

T $\mathrm{N}$ a recent number of the 'Annals of Botany' I drew attention to the 1 widespread occurrence of intrafascicular cambium in Monocotyledons. ${ }^{1}$ I have since observed it in several additional cases, including an example from each of four families (Araceae, Dioscoreaceae, Iridaceae, and Potamogetonaceae) in which, apparently, it has not hitherto been noticed. The object of the present note is to record these cases and to enumerate the cohorts and families in which instances of intrafascicular cambium have up to the present been observed.

Acorus calamus, L. (Araceae). In the Sweet Flag transverse sections close to the apex of the rhizome show cambial activity within the bundles very clearly. The lignified protoxylem and the immature metaxylem are separated from the phloem by radial files of cells (Fig. I).

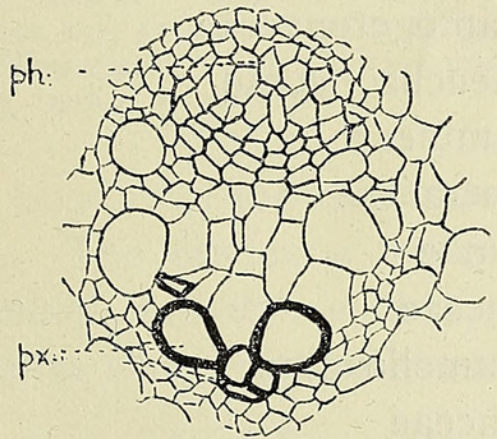

Fig. I. Acorus calamus, $L$. Transverse section of single bundle from near apex of rhizome, showing radial rows of elements between xylem and phloem $(p h$.$) . Only the protoxylem (p x$.$) is$ at present lignified. $(x, 320$.

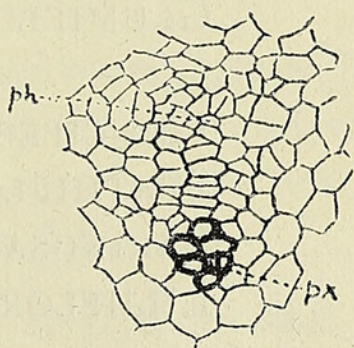

FIG. 2. Tamus communis, L. Transverse section of single bundle close to apex of aerial climbing stem, showing radial rows of elements between proto$\operatorname{xylem}\left(p x_{0}\right)$ and phloem $\left(p h_{0}\right) \cdot(\times 320$.

Tamus communis, L. (Dioscoreaceae). In the Black Bryony transverse sections close to the apex of the growing shoots reveal, within the individual bundles, a radial arrangement of the cells between the phloem and the lignified protoxylem (Fig. 2), but this indication of cambial activity is highly

1 Arber, Agnes : On the Occurrence of Intrafascicular Cambium in Monocotyledons. Ann. Bot.,

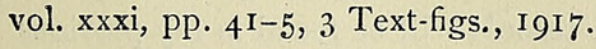

[Annals of Botany, Vol. XXXII. No. CXXV. January, 1918.] 
ephemeral. It was only observed in sections so close to the apex that the diameter of the axis was about I $\mathrm{mm}$., or, excluding the prominent leafbases, $0.5 \mathrm{~mm}$.

Tritonia, garden hybrid (Iridaceae). Traces of cambium were observed in the bundles of the very young inflorescence axis, at a stage when the diameter of the axis was less than $0.75 \mathrm{~mm}$.

Potamogeton natans, L. (Potamogetonaceac). In this species, evidence of very slight and irregular cambial activity has been found in the vascular bundles of the leaf. The same thing has been noticed in the leaves of another species, probably $P$. lucens, $\mathrm{L}$.

Ophiopogon japonicus, Ker-Gawl. (Liliaceae). In transverse sections of the inflorescence axis, the bundles are seen to be arranged in a ring. At a very young stage there are clear indications of cambial action. The radial rows of elements within the bundle in some cases involve xylem as well as phloem.

Phormium tenax, Forst. (Liliaceae). Both the xylem and phloem of the mature leaf-bundles show indications of cambial activity.

Veratrum album, L. (Liliaceae). In the mature leaf the arrangement of the phloem elements in radial files is particularly striking.

\section{List of Cohorts and Families in which one or more cases of intrafascicular cambium have been recorded. ${ }^{1}$}

\begin{tabular}{|c|c|}
\hline PANDANALES & Typhaceae \\
\hline \multirow[t]{2}{*}{ HeLobiae } & Potamogetonaceae \\
\hline & Scheuchzeriaceae \\
\hline \multirow[t]{2}{*}{ Glumiflorae } & Gramineae \\
\hline & Cyperaceae \\
\hline PRINCIPES & Palmae \\
\hline SPATHIFLORAE & Araceae \\
\hline FARINOSAE & Commelinaceae \\
\hline \multirow[t]{3}{*}{ LILIIFLORAE } & Liliaceae \\
\hline & Dioscoreaceae \\
\hline & Iridaceae \\
\hline \multirow[t]{2}{*}{ SCITAMINEAE } & Musaceae \\
\hline & Zingiberaceae \\
\hline MICROSPERMAE & Orchidaceae \\
\hline
\end{tabular}

It follows from this list that intrafascicular cambium is now known from all but two of the cohorts into which Engler divides the Monocotyledons; the exceptions are the Triuridales and the Synanthae. The Triuridales consist of a small group. of tropical saprophytes, which are not avail-

1 The references to the literature in connexion with these records will be found in my previous paper, already cited. 
able in this country, while suitable material of the few genera, such as Cyclanthus and Carludovica, which form the small cohort of the Synanthae is also difficult to obtain.

It is probable that the list of cases of intrafascicular cambium in Monocotyledons may eventually be almost indefinitely extended $;^{1}$ the most favourable place for detecting the cambium in species where it is ephemeral appears to be in the young stems at a very short distance from the growing apex, but the young leaves are sometimes equally suitable.

For comparison with the vestigial cambium of the Monocotyledons I have included two drawings (Figs. 3 and 4) showing the young and
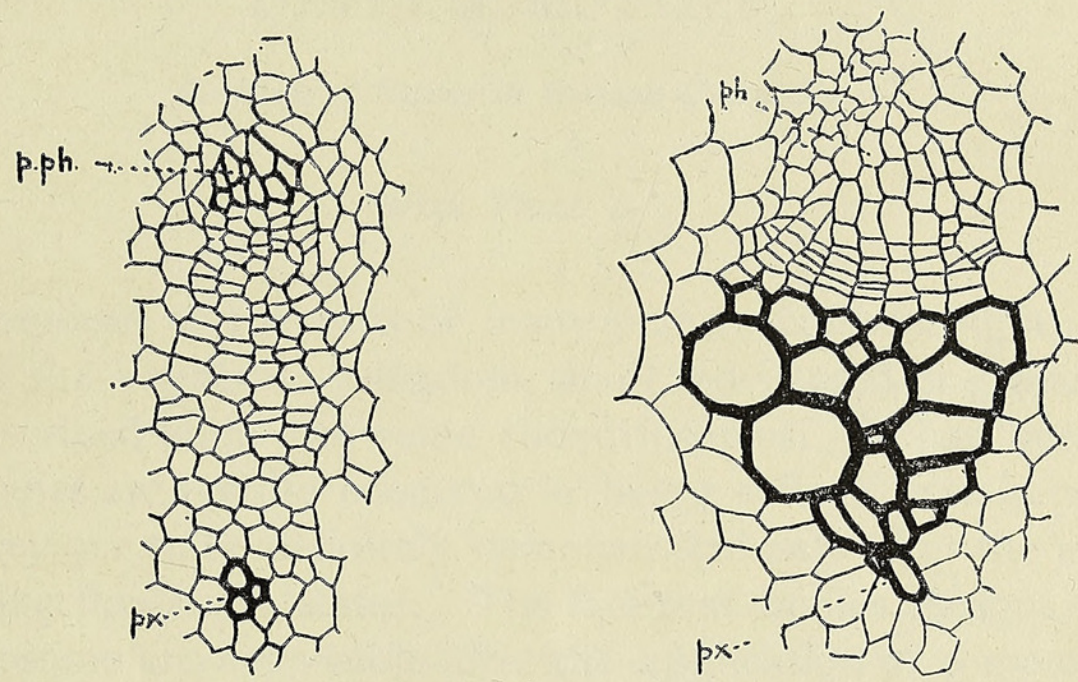

FIGS. 3 and 4. Thalictrum favum, L. Fig. 3. Transverse section of young bundle from an inforescence axis gathered June I, I9I 5 , in which only protoxylem $\left(p x_{0}\right)$ and protophloem $(p \cdot p h$. are fully differentiated. Fig. 4. Transverse section of mature bundle from infructescence axis gathered August 23, 1916. $\times 320($ circa $)$.

mature bundles of the inflorescence axis of Thalictrum flavum, L. (Ranunculaceae). The tendency towards a V-shaped xylem, and the fact that the cambial activity is chiefly directed to the production of phloem, are features which distinctly recall some of the Liliaceae.

I am indebted for material to Mr. R. I. Lynch, M.A., Curator of the Cambridge Botanic Garden, and to Mr. W. Hackett, Assistant Curator of the Liverpool Botanic Gardens. I have also to acknowledge a grant for laboratory work from the Newnham College Fellowship Committee.

Balfour laboratory, CAMBridge.

September 5, 1917 .

1 That the number of known cases might be much increased by further research has been suggested by Salisbury, E. J., Science Progress, vol. xii, pp. 4I, 42, 19 I 7 . 


\section{$2 \mathrm{BHL}$ Biodiversity Heritage Library}

Arber, Agnes Robertson. 1918. "Further notes on intrafascicular cambium in monocotyledons." Annals of botany 32, 87-89. https://doi.org/10.1093/oxfordjournals.aob.a089668.

View This Item Online: https://www.biodiversitylibrary.org/item/238284

DOI: https://doi.org/10.1093/oxfordjournals.aob.a089668

Permalink: https://www.biodiversitylibrary.org/partpdf/320208

\section{Holding Institution}

Smithsonian Libraries

\section{Sponsored by}

Biodiversity Heritage Library

\section{Copyright \& Reuse}

Copyright Status: Not in copyright. The BHL knows of no copyright restrictions on this item.

This document was created from content at the Biodiversity Heritage Library, the world's largest open access digital library for biodiversity literature and archives. Visit BHL at https://www.biodiversitylibrary.org. 